\title{
Upaya Peningkatan Cakupan Pemeriksaan Inspeksi Visual Dengan Asam Asetat (IVA) Di Dinas Kesehatan Kota Solok
}

\author{
Ridholla Permata Sari ${ }^{1}$, Abdiana $^{2}$
}

\begin{abstract}
Abstrak
Kanker serviks merupakan penyebab kematian tertinggi kedua pada wanita di negara berkembang setelah kanker payudara, diperkirakan sebesar 273.000 kematian setiap tahunnya. Tujuan: Mengetahui gambaran upaya peningkatan cakupan pemeriksaan inspeksi visual dengan asam asetat di Dinas Kesahatan Kota Solok dan merumuskan alternatif penyelesaian masalahnya. Metode: Identifikasi masalah dilakukan dengan dua pendekatan yaitu pendekatan logis dan pendekatan politis. Identifikasi masalah kesehatan melalui pendekatan logis dilakukan dengan cara melihat dan menganalisis data-data yang ada. Hasil: Masalah yang ditemukan dengan menggunakan metode USG adalah rendahnya cakupan pemeriksaan IVA di Kota Solok (19\%). Hal ini disebabkan oleh beberapa faktor yaitu kurangnya motivasi wanita usia subur (WUS) untuk pemeriksaan IVA, tidak adanya kader khusus IVA, kurangnya sosialisasi / penyuluhan pada wanita usia subur (WUS) tentang pemeriksaan IVA, kurangnya tersedia poster, brosur dan pamflet tentang IVA, serta kurangnya dukungan dari keluarga (suami). Program intervensi prioritas upaya peningkatan cakupan IVA yaitu: melakukan penyuluhan tentang kesehatan reproduksi dan tentang pemeriksaan IVA serta langsung melakukan pemeriksaan IVA gratis dan membentuk kader-kader khusus IVA untuk melakukan promosi IVA kepada masyarakat. Dalam pelaksanaan kegiatan penyuluhan IVA dan pelaksanaan pemeriksaan IVA ini digunakan Plan, Do. Check, dan Action (PDCA). Simpulan: Data yang didapatkan sekitar $88 \%$ WUS tidak pernah memeriksakan diri ke Puskesmas, hal ini karena pengetahuan masyarakat yang cukup (58\%).
\end{abstract}

Kata kunci: kanker serviks, program iva, kader, promosi kesehatan

\section{Abstract}

Cervical cancer is the second leading cause of death in women at developing countries after breast cancer, estimated at 273,000 deaths annually. Objectives: To described the efforts to increase the coverage of visual inspection with acetic acid in the Solok City Health Service and formulate alternative solutions to the problem. Methods: The identification of the problem of this research were carried out with two approaches, namely a logical approach and a political approach. Identifying health problems through a logical approach was done by looking at and analyzing existing data. Results: The problems were found by using the USG method such as the low coverage of IVA checks in Solok City (19\%). These were caused by the lack of motivation of women of childbearing age (WUS) for examination of the IVA, the absence of special cadres of IVA, lack of socialization / counseling for women of childbearing age (WUS), lack of available posters, brochures and pamphlets about IVA, and lack of support from family (husband). The intervention program prioritized efforts to increase the coverage of IVA, namely: conducting information on reproductive health and about IVA examinations and immediately conducting free IVA examinations and forming IVA special cadres to carry out IVA promotion to the community. In implementing IVA extension activities and the implementation of this IVA examination; Plan, Do, Check, and Action (PDCA). Conclusions: $88 \%$ of WUS never checked into the Puskesmas, this was due to sufficient public knowledge (58\%).

Keywords: cervical cancer, iva program, cadre, health promotion 
Affiliasi penulis: 1. Prodi Magister Kesehatan Masyarakat Fakultas Kedokteran Universitas Andalas Padang (FK Unand), 2. Bagian IImu Kesehatan Masyarakat Fakultas Kedokteran Unand.

Korespondensi: Abdiana, Email: abdiana@med.unand.ac.id HP : 082171997534

\section{PENDAHULUAN}

Kanker serviks merupakan penyebab kematian tertinggi kedua pada wanita di negara yang sedang berkembang setelah kanker payudara, diperkirakan sebesar 273.000 kematian setiap tahunnya. Kanker serviks adalah keganasan yang terjadi pada serviks (leher rahim) dan disebabkan oleh Virus HPV (Human Papiloma Virus). ${ }^{1}$ Tipe virus HPV yang banyak paling banyak dianggap sebagai penyebab kanker serviks adalah tipe 16 dan 18 yang ditemukan sebesar $70 \%$ dari laporan penelitian WHO tahun 2006. Wanita dengan seksualitas aktif beresiko terinfeksi Human Papiloma Virus (HPV) sebesar $50 \%$ sampai $80 \%{ }^{2}$

Publikasi WHO pada Global Burden Cancer (GLOBOCAN) memprediksikan bahwa kejadian dan kematian akibat kanker serviks terus meningkat, khususnya di negara yang sedang berkembang. Perkiraan kejadian per tahun pada negara yang kurang berkembang adalah 450.000 dan mortalitas lebih dari 240.000. Pada GLOBOCAN (2002) diperkirakan $80 \%$ kematian di dunia disebabkan oleh kanker serviks, sedangkan menurut GLOBOCAN (2008) adalah $88 \%$ dan akan meningkat 98\% kanker pada tahun $2030 .^{3}$

Sistem kesehatan masih kurang lengkap terutama di negara yang sedang berkembang, menyediakan pemeriksaan skrining bagi perempuan dan merupakan tantangan untuk mendapatkan wanita yang harus diskrining, follow up dan pengobatan pre kanker. Studi menunjukkan bahwa perempuan yang hanya diskrining sekali seumur hidup antara usia 30 sampai 40 tahun dapat menurunkan resiko kanker serviks sebesar $25-36 \%{ }^{4}$

Kebijakan mengenai pengendalian kanker serviks di Indonesia diatur di dalam Undang-Undang Kesehatan Nomor 36 tahun 2009 pada Pasal 161 ayat 3 yang menyebutkan bahwa manajemen pelayanan kesehatan berupa promotif, preventif, kuratif dan rehabilitatif dititikberatkan pada deteksi dini dan pengobatan penyakit tidak menular. ${ }^{5}$ Kepmenkes Nomor 430 tahun 2007 tentang pedoman pengendalian penyakit kanker dan Kepmenkes Nomor 796 tentang Pedoman Tekhnis Pengendalian Kanker Payudara dan Kanker Leher Rahim. ${ }^{6}$ Isi kebijakan deteksi dini kanker di Indonesia mengacu kepada kebijakan WHO yang melakukan pencegahan dan pengendalian kanker serviks melalui empat komponen utama yaitu primary prevention, early detection, diagnosis dan treatment serta palliative care for advance disease. ${ }^{2}$

Program deteksi dini yang telah dilakukan di Indonesia untuk mengantisipasi kanker serviks adalah dengan metode IVA (Inspeksi Visual dengan Asam Asetat) yang telah tercantum di dalam Keputusan Menteri Kesehatan Republik Indonesia Nomor 796/MENKES/SK/VII/2010 tentang pedoman teknis pengendalian kanker payudara dan kanker serviks. ${ }^{7}$ Pemerintah juga mengeluarkan peraturan baru yaitu Permenkes no. 34 th,2015 Tentang Penanggulangan Kanker Payudara Dan Kanker Leher Rahim. ${ }^{8}$

Kanker serviks merupakan jenis kanker yang paling banyak terjadi pada wanita Indonesia. Kasus kematian yang tinggi disebabkan oleh kanker serviks pada wanita Indonesia terjadi karena kanker tersebut baru diketahui setelah memasuki stadium lanjut. Faktor pemicu kanker serviks itu sendiri adalah wanita yang terinfeksi HPV, wanita yang berganti-ganti pasangan seksual, wanita yang merokok, pencucian vagina dengan anti septik yang terlalu sering, kekebalan tubuh yang rendah, dan penggunaan pil kontrasepsi. $^{9}$

Kanker leher rahim masih menjadi momok yang menakutkan bagi kaum wanita di Indonesia. Angka penderita kanker leher rahim di Indonesia yang tinggi disebabkan oleh rendahnya kesadaran wanita untuk memeriksakan kesehatan dirinya, padahal saat ini penyakit apapun sudah dapat diobati dan ditangani dengan cepat yaitu dengan pendeteksian dini yang dilakukan secara berkala sehingga dapat mengurangi resiko angka kematian. Kanker leher rahim dapat dicegah dengan cara menerapkan pola hidup bersih dan sehat, misalnya tidak melakukan hubungan seks dengan berganti-ganti pasangan. ${ }^{10}$

Program pencegahan dan pengendalian kanker serviks secara komprehensif dapat mengurangi angka kematian akibat kanker serviks pada remaja dan wanita dewasa, skrining kanker serviks secara teratur 
dengan metoda HPV test atau Inspeksi Visual Acid dan pengobatan yang sesuai dalam waktu yang lama. ${ }^{11}$

Serviks (epitel) abnormal jika diolesi dengan asam asetat 3-5 \% akan berwarna putih (epitel putih). Dalam waktu 1 sampai 2 menit setelah diolesi asam asetat efek akan menghilang sehingga pada hasil ditemukan pada serviks normal tidak ada lesi putih. Tingkat keberhasilan metode IVA dalam mendeteksi dini kanker servik yaitu 60-92\%. Sensitivitas IVA bahkan lebih tinggi dari pada pap smear. ${ }^{10}$

Kota Solok memiliki empat unit Puskesmas, dan telah melaksanakan program deteksi dini kanker servik dengan metode IVA. Pada tahun 2017 Kota Solok memiliki 9.997 wanita yang berusia 30 sampai 50 tahun, namun hanya 1.879 atau sebesar $19 \%$ wanita yang telah melakukan deteksi dini kanker servik dengan metode IVA dan enam diantaranya dinyatakan positif. ${ }^{11}$ Berdasarkan uraian diatas maka perlu dibahas upaya peningkatan cakupan pemeriksaan IVA di Kota Solok.

\section{METODE}

Penelitian ini dilakukan dengan dua pendekatan yaitu pendekatan logis dan pendekatan politis. Identifikasi masalah kesehatan melalui pendekatan logis dilakukan dengan cara melihat dan menganalisis data yang ada. Sumber informasi yang digunakan adalah Laporan Tahunan 2017 Dinas Kesehatan Kota Solok, Profil Kesehatan 2017 Dinas Kesehatan Kota Solok, Rencana Strategis Dinas Kesehatan Kota Solok 2016-2021, Laporan Program yang ada di Dinas Kesehatan Kota Solok, Hasil observasi program di Dinas Kesehatan Kota Solok dan Dokumen perencanaan kebutuhan SDMK pada Dinas Kesehatan Kota Solok Tahun 2016 dan $2017 .^{12}$

Penetapan prioritas penyebab masalah digunakan metode USG. Metode USG menggunakan kriteria sebagai berikut: U (urgency), merupakan mendesak atau tidaknya masalah diselesaikan (waktu); S (seuriousness), merupakan tingkat keseriusan, yaitu dampak masalah terhadap produktivitas, keberhasilan program dan pengaruhnya terhadap sistem; G (growth), merupakan tingkat perkembangan;apakah masalahnya berkembang sedemikian rupa sehingga sulit dicegah.
HASIL

Berdasarkan hasil diskusi yang dilakukan dengan Kepala Dinas Kesehatan Kota Solok terkait masalah yang ditemukan, maka dapat dikemukakan bahwa dalam rangka meningkatkan derajat kesehatan masyarakat perlu dilakukan intervensi. Intervensi dilakukan adalah untuk meningkatkan cakupan pemeriksaan IVA, sehingga diputuskan untuk melakukan analisis masalah yang ada pada seksi Dinas Kesehatan Kota Solok yaitu Seksi Pencegahan dan Pengendalian Penyakit khususnya pada penyakit tidak menular.

Penetapan prioritas masalah di bagian-bagian yang telah disebutkan diatas, digunakan Teknik USG. Teknik USG (Urgency,Seriousness and Growth) adalah cara semi kualitatif dalam menetapkan urutan prioritas masalah dengan memperhatikan urgensi, keseriusann dan kemungkinan berkembang (meluas) masalah yang sering disingkat sebagai metode USG.

Tabel 1. Penetapan prioritas penyebab masalah

\begin{tabular}{|c|c|c|c|c|c|c|}
\hline No & Masalah & $\mathbf{U}$ & $\mathrm{S}$ & $\mathbf{G}$ & Total & Rank \\
\hline 1 & $\begin{array}{l}\text { Rendahnya cakupan } \\
\text { penanganan } \\
\text { komplikasi neonatal }\end{array}$ & 4 & 3 & 2 & 9 & II \\
\hline 2 & $\begin{array}{l}\text { Rendahnya cakupan } \\
\text { Wus untuk } \\
\text { pemeriksaan IVA }\end{array}$ & 4 & 3 & 4 & 11 & I \\
\hline 3 & $\begin{array}{l}\text { Rendahnya cakupan } \\
\text { kunjungan ibu hamil } \\
\text { (K4) }\end{array}$ & 3 & 2 & 2 & 7 & IV \\
\hline 4 & $\begin{array}{l}\text { Rendahnya } \\
\text { persentase bayi yang } \\
\text { ditimbang berat } \\
\text { badannya D/S }\end{array}$ & 4 & 2 & 3 & 9 & III \\
\hline 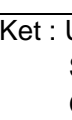 & $\begin{array}{l}J=\text { Urgency } \\
S=\text { Seuriousnes } \\
G=\text { Growth }\end{array}$ & & & & & \\
\hline
\end{tabular}

Berdasarkan penemuan diatas, maka penulis melakukan analisis terhadap masalah rendahnya cakupan Wanita Usia Subur untuk melakukan pemeriksaan IVA pada tahun 2017 yang hanya 19\% dari target $30 \%$ di Kota Solok.

\section{PEMBAHASAN}

Berdasarkan data Riset Kesehatan Dasar (Riskesdas) tahun 2013, prevalensi kejadian kanker di Indonesia sebesar 1,4\% atau sekitar 347.792 
penduduk, sedangkan kejadian kanker serviks di Indonesia menempati urutan kedua dengan prevalensi $0,8 \%$, dimana provinsi dengan prevalensi tertinggi yaitu di Kepulauan Riau, Maluku Utara dan D.I. Yogyakarta.Prevalensi kejadian kanker di Sumatera Barat berdasarkan data Riskesdas Provinsi Sumatera Barat tahun 2013 sebesar 1,7\%, dimana Kota Padang menempati urutan kelima dengan prevalensi $2,5 \%$. Prevalensi kanker serviks di Sumatera Barat sebesar 0,9\%. Prevalensi kanker serviks di Sumatera Barat $(0,9 \%)$ melebihi prevalensi Indonesia $(0,8 \%)$. Menurut Yayasan Kanker Indonesia (YKI), Sumatera Barat merupakan provinsi kedua dengan jumlah kanker serviks tertinggi dengan daerah Padang dan Solok sebagai penyumbang terbanyak. ${ }^{13}$

Kota Solok memiliki empat unit Puskesmas, yang telah melaksanakan program deteksi dini kanker servik dengan metode IVA. Pada tahun 2017 Kota Solok memiliki 9.997 wanita yang berusia 30-50 tahun, namun hanya 1.879 atau sebesar $19 \%$ wanita yang telah melakukan deteksi dini kanker serviks dengan metode IVA dan 6 diantaranya dinyatakan positif. ${ }^{12}$ Angka cakupan yang masih rendah terhadap pemeriksaaan IVA di Kota Solok, maka upaya yang dapat dilakukan untuk menanggulangi masalah ini yaitu dengan melakukan penyuluhan kepada Wanita Usia Subur yang ada disekitaran wilayah Dinkes Kota Solok. Penyuluhan ini dilakukan untuk menambah pengetahuan WUS tentang pentingnya melakukan pemeriksaan IVA.Selain itu penyuluhan juga dilakukan kepada suami agar dapat memberikan dukungan kepada pasangannya untuk melakukan pemeriksaan IVA.

Upaya promosi kesehatan diperlukan alat bantu dan media untuk menyampaikan pesan agar tujuan promosi tercapai secara maksimal. Salah satu media promosi tersebut adalah media cetak seperti brosur, poster, leaflet dan lain sebagainya. Media informasi merupakan sarana atau upaya untuk menampilkan pesan atau informasi yang ingin disampaikan oleh komunikator sehingga sasaran dapat meningkatkan pengetahuan yang diharapkan dapat merubah perilaku ke arah postif terhadap masalah kesehatan. ${ }^{14}$

Leaflet merupakan media statis dan mengutamakan pesan-pesan visual yang pada umumnya terdiri dari gambaran sejumlah kata, gambar atau foto atau tata warna. Fungsi utama adalah untuk memberikan informasi dan menghibur. Kelebihannya adalah tahan lama, mencakup banyak orang, biaya tidak tinggi, tidak perlu listrik, dapat dibawa kemana-mana, dapat mengungkit rasa keindahan, memudahkan pemahaman dan meningkatkan gairah belajar. ${ }^{15}$

Intervensi yang dilakukan oleh penulis lebih bersifat membangun perilaku, hal ini dikarenakan dalam memanfaatkan pelayanan program IVA di Puskesmas, perubahan perilaku akan lebih memberi daya ungkit yang kuat. Intervensi dalam bentuk bekerja sama dengan kegiatan PIS-PK untuk melakukan promosi tentang program IVA yang dilakukan puskesmas dan bekerja sama dengan program PIS-PK untuk melakukan promosi tentang pelayanan program IVA yang dilakukan puskesmas, dengan harapan kegiatan ini dapat meningkatkan jumlah cakupan IVA di puskesmas.

Pada kegiatan ini, kontak langsung dilakukan dengan masyarakat dan meyakinkan secara langsung kepada masyarakat bahwa pemeriksaan IVA yang dilakukan di Puskesmas juga aman dan nyaman. Kegiatan ini juga dapat memberikan informasi tentang kenapa masyarakat kurang berminat untuk melakukan pemeriksaan IVA di Puskesmas.

Intervensi ini merupakan salah satu contoh metode promosi individual (perorangan). Metode yang bersifat individual ini digunakan untuk membina perilaku baru atau membina seseorang yang telah mulai tertarik kepada suatu perubahan perilaku atau inovasi. Dasar kenapa metode ini digunakan karena masing-masing individu mempunyai masalah atau alasan yang berbeda-beda dan ini juga berhubungan dengan penerimaan atau perilaku baru tersebut. ${ }^{14}$

Perubahan perilaku dari sisi provider atau tenaga kesehatan yaitu bidan yang telah dilatih. Diantara kegiatan yang direncanakan tersebut yaitu bidan puskesmas/pustu/poskeskel harus melakukan promosi tentang pelayanan pemeriksaan IVA yang dilakukan di Puskesmas/pustu/poskeskel. Melakukan pendekatan persuasif kepada WUS agar mau melakukan pemeriksaan IVA dipuskesmas.

Usulan rencana pelaksanaan alternatif pemecahan masalah yang ditawarkan yaitu penyuluhan tentang IVA dan pembentukan kader- 
kader khusus IVA. Intervensi yang akan dilakukan adalah melakukan penyuluhan kepada masyarakat tentang IVA dan melaksanakan pemeriksaan IVA gratis. Kegiatan ini dilakukan agar meningkatkan pengetahuan WUS tentang perlunya pemeriksaan IVA dan termotivasi untuk melakukan pemeriksaan IVA.

Pelaksanaan kegiatan penyuluhan IVA dan pemeriksaan IVA diperlukan Plan, Do, Check, Action (PDCA) sebagai berikut.

\section{Plan (Perencanaan)}

Perencanaan adalah kegiatan merumuskan tugas dan tanggungjawab, peningkatan pengetahuan, serta sasaran kegiatan. Sasaran kegiatan ini adalah semua Pasangan Usia Subur di Wilayah Kerja Dinas Kesehatan Kota Solok.

Perencanaan dilakukan setelah melalui beberapa tahap analisis, mulai dari analisis masalah (berdasarkan data yang ada di Dinas Kesehatan Kota Solok dan hasil wawancara mendalam dengan kepala bidang pelayanan kesehatan, pemegang program dan pihak puskesmas), menganalisis penyebab masalah dengan menggunakan metode fishbone sehingga setelah itu dapat dilakukan scoring terhadap penyebab masalah untuk ditentukan alternatif pemecahan masalahnya.

Hasil analisis tersebut ditemukan masalah rendahnya Cakupan Pemeriksaan IVA yang hanya 19\% dari target nasional 30\% (tahun 2017). Prioritas penyebab masalah yang akan difokuskan kepada kurangnya penyuluhan yang dilakukan oleh pihak puskesmas kepada masyarakat. Alternatif masalah yang akan dilaksanakan yaitu dengan melaksanakan penyuluhan dan pemeriksaan IVA serentak secara gratis kepada WUS.

Rincian perencanaan kegiatan penyuluhan dan pemeriksaan IVA telah diterangkan di dalam POA.

\section{Do (Pelaksanaan)}

Pelaksanaan adalah melakukan dan menerapkan prosedur-prosedur kerja dan instruksi kerja sesuai aktifitas yang telah disusun dalam perencanaan. Pelaksanaan harus implementasikan apa yang direncanakan. Pada tahapan pelaksanaan ini diharapkan semua pihak yang terlibat dalam kegiatan dapat bertindak sesuai tanggungjawab masing-masing sehingga apa yang telah direncanakan dapat berjalan sesuai dengan apa yang diharapkan.

Pelaksanaan penyuluhan dilakukan secara rutin dan menyeluruh untuk meningkatkan tingkat pengetahuan dan motivasi masyarakat tentang pentingnya pencegahan kanker leher rahim.Penyuluhan diadakan melalui kerjasama dari puskesmas dengan pihak luar seperti tokoh agama dan sponsor bakti sosial. Sasaran penyuluhan tidak hanya kepada kelompok wanita, tetapi juga kepada kelompok pria (suami) untuk meningkatkan pengetahuan dan kesadaran untuk mengijinkan wanita (istri) melakukan pemeriksaan IVA.

Pelaksanaaan deteksi dini kanker serviks berdasarkan petunjuk teknis pelaksanaan meliputi pendaftaran dengan membagikan nomor urut, pembuatan kartu status, pemanggilan klien dan suami, pemberian konseling dan informed consent, pemeriksaan payudara dengan cara $C B E$ oleh bidan dengan konfirmasi dokter puskesmas oleh dokter puskesmas bila ditemukan benjolan, pelaksanaan IVA oleh bidan dengan konfirmasi dokter puskesmas, pelaksanaan oleh dokter/ bidan puskesmas untuk IVA positif, penjelasan rencana tindak lanjut baik pada kasus positif maupun negatif, pencatatan dan pelaporan pada formulir yang telah tersedia dan pemulangan pasien. Pelaksanaan kegiatan program IVA sesuai dengan petunjuk teknis tersebut. Pelaksanaan pemeriksaan IVA dilakukan sesuai prosedur yang disesuaikan dengan tempat pelayanan didalam maupun diluar gedung. ${ }^{16}$

\section{Pemeriksaan (Check)}

Check merupakan rangkaian kegiatan yang terdiri dari pemeriksaan, memonitoring, mengecek, mengukur, mengevaluasi dan mengoreksi intervensi yang telah dilakukan apakah hasil yang terjadi sesuai dengan yang direncanakan atau tidak. Check juga dapat digunakan untuk memantau atau mengukur proses dan hasil yang terjadi apakah sesuai dengan rencana mutu, sasaran mutu, persyaratan yang ditetapkan, mengevaluasi dan melaporkan hasilnya.

Pemeriksaan yang dapat dilakukan, apakah penyuluhan tentang IVA telah rutin dilakukan sehingga bisa meningkatkan pengetahuan dan motivasi Wanita Usia Subur (WUS) untuk melakukan pemeriksaan IVA. 


\section{Tindakan (Act)}

Tahap act adalah tahap untuk mengambil tindakan yang seperlunya terhadap hasil check. Berdasarkan konsep check dapat disimpulkan apakah indikator kegiatan tercapai atau belum. Tindak lanjut yang dapat dilakukan adalah bekerjasama dengan PIS-PK pada setiap pendataan kerumah penduduk untuk dilakukan penyuluhan door to door sehingga dapat mensosialisasikan program pemeriksaan IVA langsung kepada masyarakat.

Penyuluhan jika tidak berlanjut dan belum ada peningkatan cakupan pemeriksaan IVA, maka dapat dikatakan bahwa strategi yang dimiliki masih mempunyai kekurangan, sehingga perlu perbaikan dan perencanaan intervensi lain yang lebih baik dan dapat memberikan perubahan sesuai dengan apa yang diharapkan.

\section{Intervensi Pembentukan Kader-kader IVA}

Kader merupakan ujung tombak dilapangan, yang berhadapan langsung dengan masyarakat yang sangat variatif tingkat sosialnya, dari yang tinggi sampai yang rendah sekalipun. Agar mampu berkoordinasi dan berkomunikasi dengan kepercayaan diri yang optimal, maka kader perlu dibekali berbagai ilmu dan ketrampilan baik yang bersifat materisubstansi teknis, maupun yang bersifat non-teknis, seperti hal yang terkait pengembangan diri. Penguatan teknis dapat dilakukan dengan pelatihan ataupun refreshing, tukar menukar informasi, kunjungan lapangan ke lain daerah, dan lain-lain. Kemampuan non-substansi teknis dapat dilakukan dengan berbagai cara, misal pelatihan kepemimpinan, pengembangan diri, dan lain-lain.

Pada saat sebelum pelatihan berlangsung, peserta pelatihan kader ditanyakan secara lisan tentang pengetahuan mereka tentang kesehatan reproduksi. Didapatkan secara garis besar, banyak kader yang tidak mengetahui tentang kesehatan reproduksi seperti cara membersihkan alat reproduksi luar serta adanya deteksi dini kanker organ reproduksi.

Pelaksanaan pelatihan setelah satu bulan, maka para kader diberikan angket untuk diisi tentang pengetahuan mereka tentang kesehatan reproduksi serta tanggapan mereka tentang pelatihan yang telah dilaksanakan. Hasil angket yang telah diisi akan dianalisis untuk mendapatkan sejauh mana kemampuan peserta dalam mengingat materi pelatihan serta manfaat pelatihan dari pendapat para peserta.

\section{SIMPULAN}

Masalah yang ditemukan dengan menggunakan metode USG adalah masih rendahnya cakupan pemeriksaan iva di Kota Solok. Hal ini disebabkan oleh beberapa faktor yaitu kurangnya motivasi wanita usia subur (WUS) yang sudah melakukan hubungan seksual untuk pemeriksaan iva, tidak adanya kader khusus untuk mengajak masyakat untuk dilakukan pemeriksaan IVA, kurangnya sosialisasi / penyuluhan pada wanita usia subur (wus) yang sudah melakukan hubungan seksual tentang pemeriksaan iva, kurangnya tersedia poster, brosur dan pamflet tentang iva, dan kurangnya dukungan dari keluarga (suami). Dalam pelaksanaan kegiatan penyuluhan IVA dan pelaksanaan pemeriksaan IVA ini digunakan Plan, Do. Check, dan Action (PDCA). Sekitar $88 \%$ WUS tidak pernah memeriksakan diri ke Puskesmas, hal ini karena pengetahuan masyarakat yang cukup (58\%).

\section{SARAN}

Dinas Kesehatan Kota Solok dan puskesmas yang berada dilingkungan kota Solok agar lebih meningkatkan promosi dan sosialisasi mengenai IVA supaya dapat meningkatkan pengetahuan dan motivasi Wanita Usia Subur melakukan pemeriksaan IVA serta untuk meningkatkan cakupan pemeriksaan IVA tersebut.

\section{UCAPAN TERIMAKASIH}

Terimakasih kepada kantor Dinas Kesehatan Kota Solok beserta jajarannya dan seluruh pihak yang turut membantu dalam menyelesaikan penelitian ini.

\section{DAFTAR PUSTAKA}

1. American College of Clinical Pharmacy (ACCP). Planning and implementing cervical cancer prevention and control program: a manual for manager A. f. C. C. prevention. ACCP; 2004. 
2. World Health Organization (WHO). Comprehensive cervical cancer control: a guide to essensial practice. Geneva: WHO; 2006.

3. Global Burden Cancer (Globocan). Estimated cancer insidence, mortality, prevelence and disability-adjusted life years (DALYs) Worldwide. Globocan; 2012. hlm.11.

4. Goltz S, Innovation S, Kenny A, Rosella K. Delivering cervical cancer prevention in the developing world; 2011.

5. Kementerian Kesehatan RI (Kemenkes Rl). Manajemen pelayanan kesehatan. Jakarta: Kemenkes RI ; 2009. hIm.1-48

6. Kemenkes RI. Pedoman pengendalian penyakit kanker. Jakarta: Kemenkes RI; 2007.

7. Kemenkes RI. Keputusan menteri kesehatan RI nomor 796/Menkes/SK/VI/2010 tentang pedoman tekhnis pengendalian kanker payudara dan kanker leher rahim. Jakarta: Kemenkes RI; 2010.

8. Kemenkes RI. Peraturan pemerintah no. 34 tahun 2015 tentang penanggulangan kanker payudara dan kanker leher rahim. Jakarta: Kemenkes RI; 2015.

9. Wahyuni S. Faktor-faktor yang mempengaruhi perilaku deteksi dini kanker serviks di kecamatan Ngampel Kabupaten Kendal Jawa Tengah. Jurnal Keperawatan Maternal.2013;1(1):55-60.

10. Setiati E. Waspadai 4 kanker ganas pembunuh wanita. Edisi ke-I. Yogyakarta: CV Andi Offset; 2009.

11. American College of Clinical Pharmacy (ACCP). Recent evidence on cervical cancer screening in low-resource settings. London: ACCP; 2011.

12. Dinas Kesehatan Kota Solok (DKK Solok). Profil dinas kesehatan kota Solok. Solok: DKK Solok; 2018.

13. Yayasan Kanker Indonesia (YKI). Cakupan deteksi dini kanker serviks. Jakarta: YKI-Jakarta Race; 2018.

14. Notoatmodjo S. Kesehatan masyarakat ilmu dan seni. Jakarta: PT Rineka Cipta; 2007.

15. Notoatmodjo S. Metode penelitian kesehatan. Jakarta: PT Rineka Cipta; 2005.

16. Departemen Kesehatan RI (Depkes Rl). Pencegahan kanker rahim dan kanker payudara. Jakarta: Direktorat Jenderal Pemberantasan Penyakit dan Penyehatan Lingkungan Depkes RI; 2009. 